\title{
Sistem Monitoring Pendeteksi Kebocoran LPG berbasis Mikrokontroller ATmega16 menggunakan RF APC220
}

\author{
RATNA SUSANA, DECY NATALIANA, UMMI ATIAH \\ Teknik Elektro Institut Teknologi Nasional (ITENAS) Bandung \\ Email : ratnassn@yahoo.com
}

\begin{abstract}
ABSTRAK
Penggunaan LPG sebagai bahan bakar alternatif pengganti bahan bakar minyak dirasakan lebih efektif dan praktis. Namun kandungan senyawa di dalamnya memiliki efek yang negatif jika menguap di udara bebas. Sistem detektor gas LPG dapat menjadi salah satu solusi untuk mengetahui lebih dini terjadinya kebocoran gas. Implementasi sistem detektor gas LPG pada penelitian ini berupa sistem monitoring nirkabel yang dilengkapi alarm sebagai indikasi jika terjadi kebocoran gas. Sistem terdiri dari bagian Remote Controller dan Master Controller. Remote Controller menggunakan mikrokontroler ATMega16 yang terintegrasi dengan sensor MQ5, LCD dan transceiver RF APC220. Sedangkan Master Controller berupa komputer (PC) yang dapat menampilkan kondisi ruangan yang dideteksi oleh bagian Remote Controller. Sistem berhasil mendeteksi gas LPG dan menampilkan kadar konsentrasinya dalam rentang 200 sampai dengan 1000 ppm. Ketika kadar konsentrasi gas mencapai 5000 ppm, alarm aktif secara otomatis dan memberikan status waspada. Pengiriman data secara nirkabel dengan adanya sejumlah penghalang berhasil dilakukan sampai jarak $200 \mathrm{~m}$.
\end{abstract}

Kata kunci: Sistem Monitoring, Remote Controller, Master Controller, LPG, RF APC220

\begin{abstract}
The use of $L P G$ as a fuel alternative to fossil fuels may be more effective and practical. Neverfluless its compound has a negative effect if it evaporates to the air. LPG gas detector system may be one solution to determine the early occurrence of gas leak. The detector system implementation in this study was a wireless monitoring system that had alarm to indicate if there was the gas leak. The system consisted of the Remote Controller and the Master Controller. Remote Controller used ATmega16 microcontroller integrated with MQ5 sensor, LCD and RF transceiver APC220. While the Master Controller in the form of a computer $(P C)$ that could display a room condition was detected by the Remote Controller section. LPG gas system successfully detected and displayed the levels of concentration in 200 up to 1000 range ppm. When the concentration of gas reached 5000 ppm, the alarm activated automatically and provided alert status. The wirelless sending data with a number of barriers was carried out successfully up to a distance of $200 \mathrm{~m}$.
\end{abstract}

Keywords: Monitoring System, Remote Controller, Master Controller, LPG, RF APC220 


\section{PEndahuluan}

LPG (Liquefied Petroleum Gas) sebagai bahan bakar alternatif pengganti minyak tanah dengan bensin. Bahan bakar dengan wujud gas ini mempunyai efek yang negatif, yaitu apabila menguap di udara bebas, maka akan membentuk lapisan. Lapisan yang terbentuk ini bersifat mudah terbakar, sehingga sangat berbahaya apabila terjadi penumpukkan di dalam ruangan tertutup dan berpotensi menyebabkan percikan api. Walaupun LPG yang dipasarkan di Indonesia telah dilengkapi zat odor yang berbau menyengat, pengguna seringkali masih kurang berhati-hati. Oleh karena itu penelitian terhadap sistem detektor dapat menjadi solusi sebagai pemberi peringatan dini terhadap kebocoran dari gas LPG.

Menurut Badan Perlindungan Konsumen Nasional (BPKN, 2010) dalam kasus ledakan tabung gas mengatakan bahwa LPG juga memiliki sifat dan kelakuan yang sangat berbahaya karena mudah terbakar dan mudah meledak, tidak beracun tapi jika terhirup lebih dari 1.000 ppm atau $0,1 \%(100 \%=1.000 .000 \mathrm{ppm})$ akan menyebabkan mengantuk, mimpi kemudian meninggal. Gas LPG dapat menyebabkan ledakan pada konsentrasi gas 1,8\% s/d 10\%.

Arif dalam dalam penelitiannya mengenai pengembangan dan evaluasi sistem peringatan dini kebocoran LPG rumah tangga, menjelaskan bahwa sensor MQ5 mempunyai sensitivitas yang tinggi terhadap propana dan butana sehingga sangat cocok memonitor keberadaan gas LPG. Sensor ini juga mempunyai sensitivitas yang rendah terhadap uap alkohol yang biasa terdapat pada interferensi gas, sehingga cocok untuk sistem peringatan gas (Arif Nurhidayat, 2010).

Perancangan yang dilakukan Huda (Huda Ilal Kirom, dkk, 2013) dalam jurnalnya yang berjudul Sistem Monitoring Kebocoran Gas LPG pada Smart Building Berbasis TCP/IP mengatakan bahwa dengan adanya sistem monitor dan kendali secara terpusat pada sebuah gedung, maka akan meningkatkan efektifitas serta efisiensi energi sebuah bangunan. Sistem monitoring kebocoran gas LPG dan mencegah kebocoran gas berlanjut, sehingga dapat meminimalisir ledakan akibat kebocoran gas.

Dalam proses pengiriman informasi, komunikasi nirkabel dirasakan lebih efektif dan praktis. Seperti yang ditullis oleh pusdriyanto (Pusdriyanto Wibowo, 2012) Beberapa keunggulannya yang diberikan oleh sistem komunikasi nirkabel, yaitu:

a. Mobilitas, dapat digunakan kapan saja dan dimana saja

b. Kecepatan installasi, proses jaringan ini cepat dan mudah

c. Fleksibilitas tempat, sangat fleksibel terhadap tempat

d. Pengurangan anggaran biaya, lebih hemat

e. Kemampuan jangkauan, jangkauannya luas

Berdasarkan beberapa kajian pustaka yang telah dilakukan beberapa penulis, maka penelitian ini dilakukan untuk pendeteksian dini terhadap kebocoran gas LPG dengan menggunakan sensor gas yang dilengkapi sistem monitoring sehingga dapat memantau dari jarak jauh dan dapat ditampilkan pada sebuah PC (Personal Computer) dengan pengaplikasian komunikasi nirkabel berupa RF (Radio Frequency) dalam media pengiriman datanya. 


\section{PERANCANGAN DAN REALISASI SISTEM}

\subsection{Gambaran Umum Sistem}

Prinsipnya sistem dalam penelitian ini terdiri dari 2 (dua) bagian perangkat, yaitu Remote Controller dan Master Controller yang ditunjukkan pada Gambar 1.

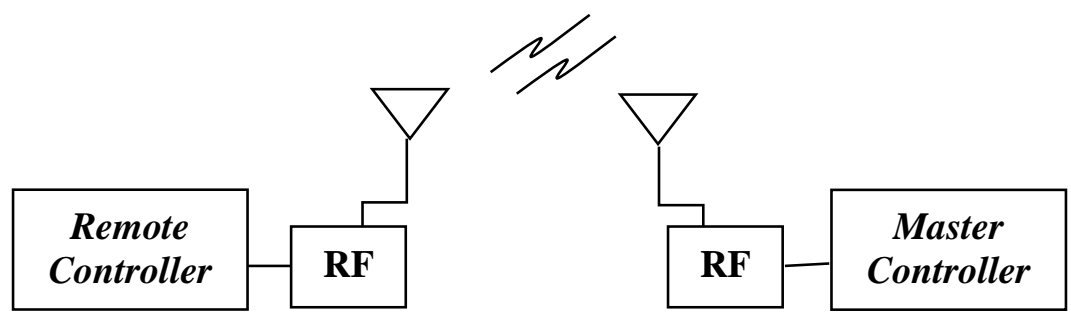

Gambar 1. Blok diagram sistem secara umum

Remote Controller merupakan suatu rangkaian elektronik yang telah dilengkapi dengan sensor gas MQ5 yang dihubungkan pada kabel konektor sebagai sistem pendeteksi keberadaan gas LPG. Sedangkan Master Controller merupakan sebuah PC (Personal Computer) yang memonitor kondisi ruang pada Remote Controller. Sistem komunikasi antara Remote Controller dan Master Controller menggunakan komunikasi frekuensi radio nirkabel dengan mengaplikasikan modul RF (Radio Frequency) APC220 yang dipasang pada masing-masing perangkat.

Prinsip kerja sistem, yaitu:

a. Sistem dibangun dari 2 (dua) bagian, yaitu perangkat Remote Controller dan perangkat Master Controller.

b. Perangkat Remote Controller merupakan perangkat elektronik yang terdiri dari sensor gas, mikrokontroller sebagai pengendali serta sistem alarm berupa buzzer dan lampu indikator.

c. Perangkat Remote Controller dapat dikontrol dan dipantau melalui Master Controller secara nirkabel dengan menggunakan modul tranceiver RF sebagai media transmisi informasinya.

d. Sensor gas mendeteksi berdasarkan perubahan resistansi sensor yang menyebabkan perubahan tegangan keluaran (Vout) sebagai keluaran dari sensor.

e. Keluaran sensor gas berupa tegangan analog yang kemudian akan dikelolah pada ADC mikrokontroller sehingga dihasilkan kadar konsentrasi gas dalam satuan ppm.

f. Sistem alarm dapat aktif apabila konsentrasi gas telah melebihi kadar konsentrasi tertentu.

g. Pada perangkat Master Controller terdapat sebuah PC (Personal Computer) yang dapat menampilkan informasi data yang telah dikirimkan oleh Remote Controller.

h. Tampilan informasi atau data pada PC ditampilkan dalam bentuk visualisasi.

\subsection{Perancangan dan Realisasi Perangkat Keras (Hardware)}

Spesifikasi sistem yang dirancang dan direalisasikan harus mampu melakukan beberapa proses yaitu:

a. Sistem dapat mendeteksi gas LPG dan menampilkan kadar konsentrasi gas, dalam satuan ppm.

b. Sistem dapat melakukan monitoring jarak jauh secara nirkabel. 
c. Sistem terdiri dari sebuah perangkat Remote Controller dan Master Controller.

d. Sistem dapat memberikan indikator alarm, jika konsentrasi gas telah mencapai 5000 ppm.

e. Tampilan visual pada PC berupa kadar konsentrasi gas dan dilengkapi dengan sistem mute (sunyi).

f. Jarak jangkauan sistem dapat mencapai $\pm 1000 \mathrm{~m}$, sesuai spesifikasi RF APC220.

Berdasarkan spesifikasi sistem yanng diinginkan, maka perancangan dan realisasi sistem untuk perangkat keras (hardware) dibagi atas 2 (dua) bagian, yaitu pada perangkat Remote Controller dan perangkat Master Controller.

\subsubsection{Perancangan dan Realisasi Perangkat Keras Remote Controller}

Blok diagram sistem untuk perangkat Remote Controller ditunjukkan pada Gambar 2.

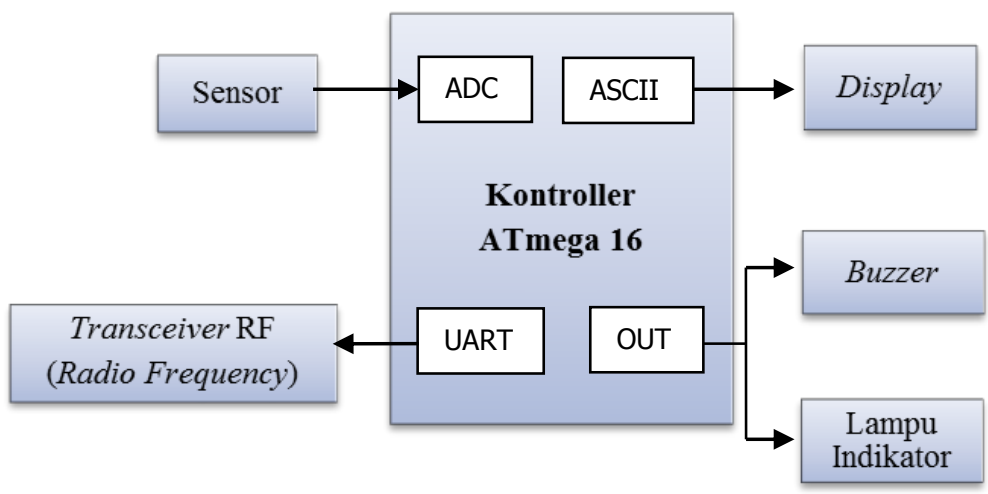

Gambar 2. Blok diagram perangkat Remote Controller

Berdasarkan blok diagram pada Gambar 2, maka Remote Controller terdiri dari beberapa subsistem, yaitu:

1. Subsistem Pengendali

Mikrokontroler ATmega16

2. Subsistem Sensor

Sensor Gas MQ5

3. Subsistem Tampilan (Display)

LCD JHD204

4. Subsitem Komunikasi Serial

transceiver RF (Radio Frequency) APC220

5. Subsistem Alarm

Buzzer SFM-27

Lampu indikator

6. Subsitem Catu daya

Catu daya 5 VDC

Catu daya 12 VDC 


\section{Subsistem Pengendali}

Sistem minimum mikrokontroller dalam sistem yang dirancang ini menggunakan mikrokontroller ATmega16 yang berfungsi sebagai unit pengendali yang akan mengolah informasi. Pin-pin pada mikrokontroller akan dihubungkan terhadap port-port pada komponen lainnya yang terlihat pada skematik subsistem pengendali Gambar 3.

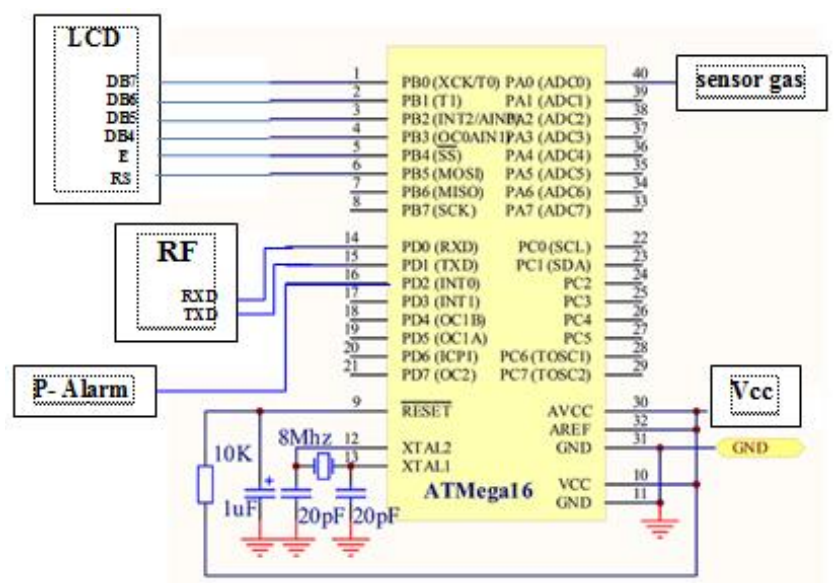

Gambar 3. Skematik subsistem pengendali

\section{Subsistem Sensor}

Pada rangkaian sensor ini terdapat rangkaian pembagi tegangan yang ditambahkan resistor sebesar $20 \mathrm{~K} \Omega$ sebagai resistansi beban, yang akan menghasilkan output berupa tegangan analog. Apabila terjadi perubahan resistansi pada sensor, maka akan menyebabkan tegangan keluaran (Vout) berubah. Skematik subsistem sensor ditunjukkan pada Gambar 4.

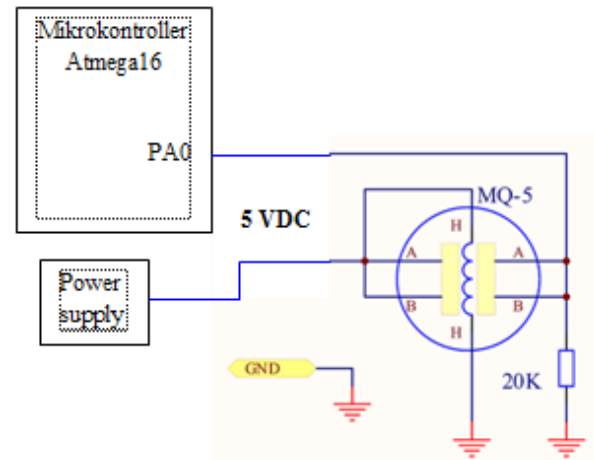

Gambar 4. Skematik subsistem sensor

Dalam rangkaian subsistem sensor $\mathrm{RL}$ yang dipakai sebesar $20 \mathrm{~K} \Omega$, seperti yang disarankan dalam datasheet (datasheet sensor MQ5) untuk rangkaian sensor yang diaplikasikan pada $L P G$, disarankan menggunakan resistansi beban $(R L)$ sebesar $20 K \Omega$.

\section{Subsistem Tampilan (Display)}

LCD yang dipakai adalah LCD berukuran 20x4 tipe JHD204, karena informasi yang akan ditampilkan pada LCD cukup banyak, maka pemilihan terhadap penggunaan jenis LCD JHD204 yang berukuran lebih besar. Skematik subsistem tampilan ditunjukkan pada Gambar 5. 


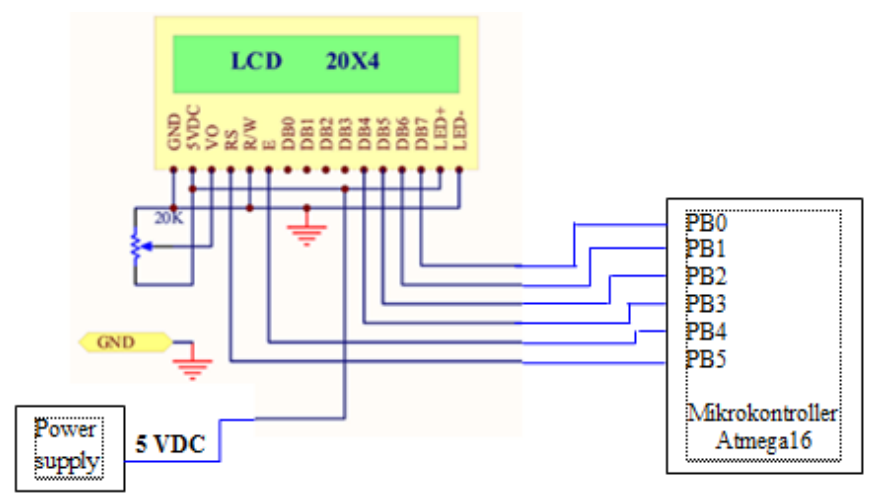

\section{Gambar 5. Skematik subsistem tampilan (display)}

\section{Subsistem Alarm}

Subsistem alarm pada sistem ini terdiri dari buzzer dan lampu indikator sebagai pemberi peringatan apabila kadar konsentrasi gas LPG telah mencapai 5000 ppm. Untuk skematik subsistem alarm ditunjukkan pada Gambar 6.

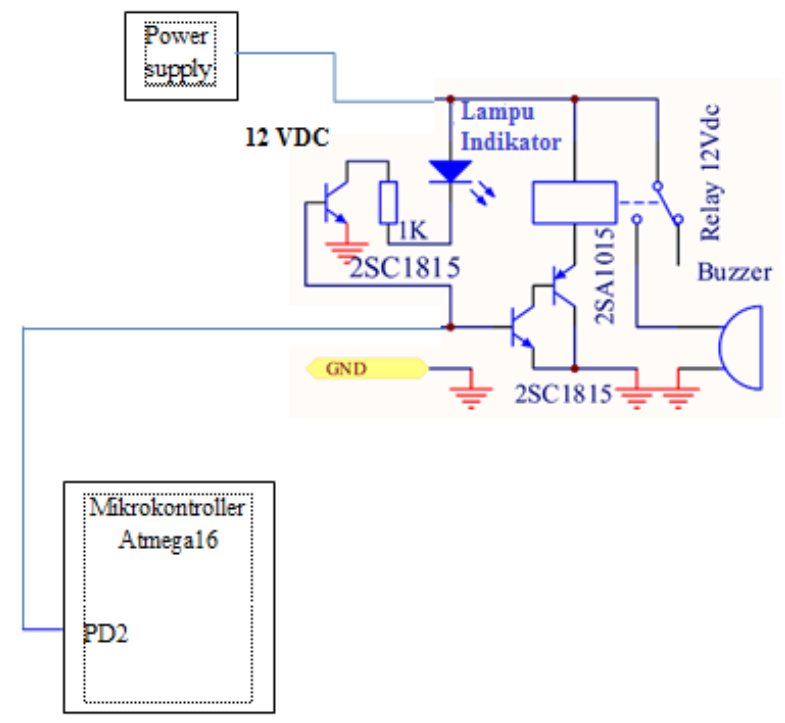

Gambar 6. Skematik subsistem alarm

\section{Subsistem Komunikasi Serial}

Pada perangkat Remote Controller, subsistem komunikasi serial digunakan sebagai media pengiriman dalam komunikasi serial data yang telah diolah sebelumnya oleh mikrokontroller dan dikirimkan menuju PC, dan sebaliknya, subsistem ini difungsikan sebagai penerima perintah dari PC yang selanjutnya diolah kembali oleh mikrokontroller. Skematik subsistem komunikasi serial pada Remote Controller ditunjukkan pada Gambar 7. 


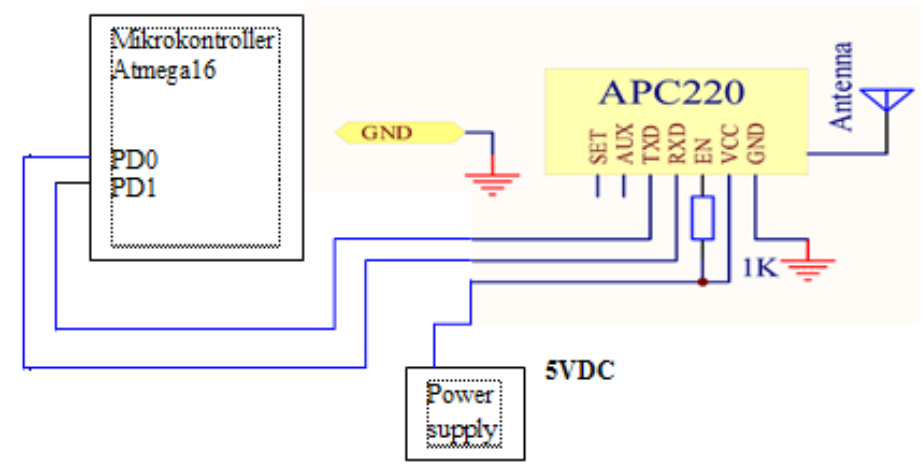

Gambar 7. Skematik subsistem komunikasi serial Remote Controller

\section{Subsistem Catu Daya}

Dalam subsistem catu daya, sumber tegangan sistem berasal dari jala-jala listrik PLN 220 VAC atau dapat berasal dari 2 (dua) buah baterai berjenis Non-Spillable jenis KB6-1.3 (6v $1.3 \mathrm{Ah} / 20 \mathrm{HR}$ ) yang masing-masing sebesar $6 \mathrm{VDC}$.

Untuk mendapatkan sumber tegangan sebesar 5 VDC ini, maka catu daya dihubungkan dengan 4 (empat) buah regulator 7805 yang masing-masing dihubungkan pada kapasitor sebesar $220 \mu \mathrm{F}$ yang difungsikan sebagai filter pada rangkaian power supply. Sedangkan pada subsistem alarm supply tegangan yang dibutuhkan adalah sebesar 12 VDC, sehingga tidak diperlukan lagi penambahan regulator untuk menghasilkan tegangan yang diinginkan. Gambar 8 menunjukkan skematik dari subsistem catu daya.

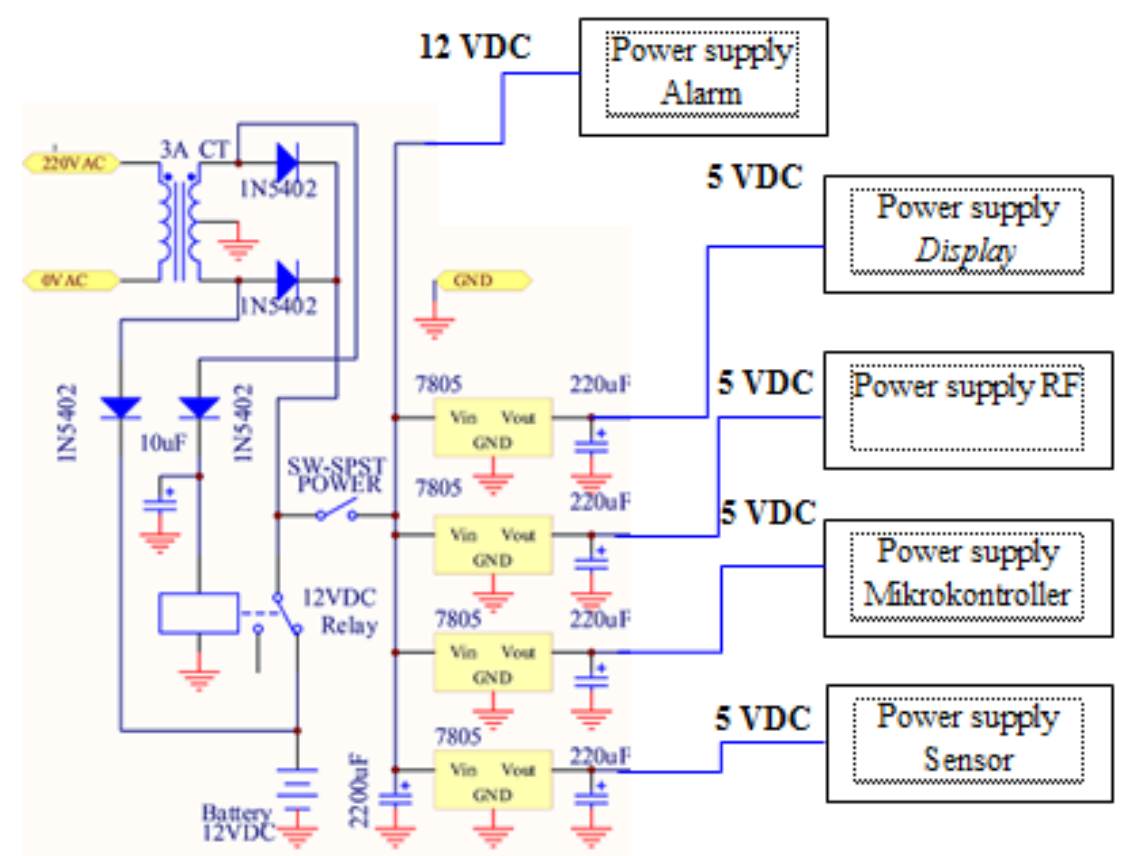

Gambar 8. Skematik subsistem catu daya 
Untuk integrasi rangkaian keseluruhan sistem pada perangkat Remote Controller ditunjukkan pada Gambar 9.

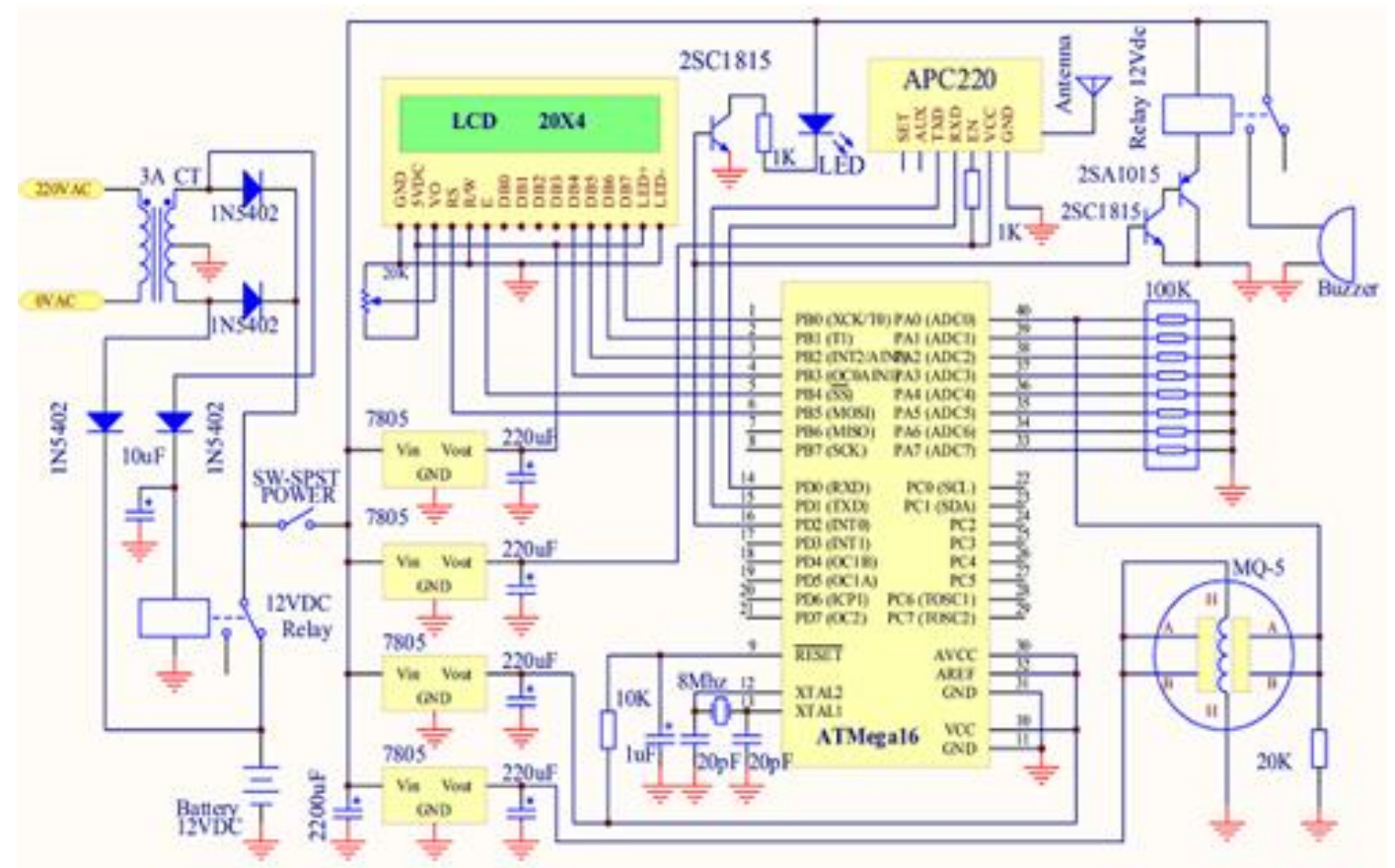

Gambar 9. Rangkaian keseluruhan perangkat Remote Controller

Untuk realisasi dari integrasi keseluruhan subsistem dari perangkat keras (hardware) pada Remote Controller terlihat pada Gambar 10.

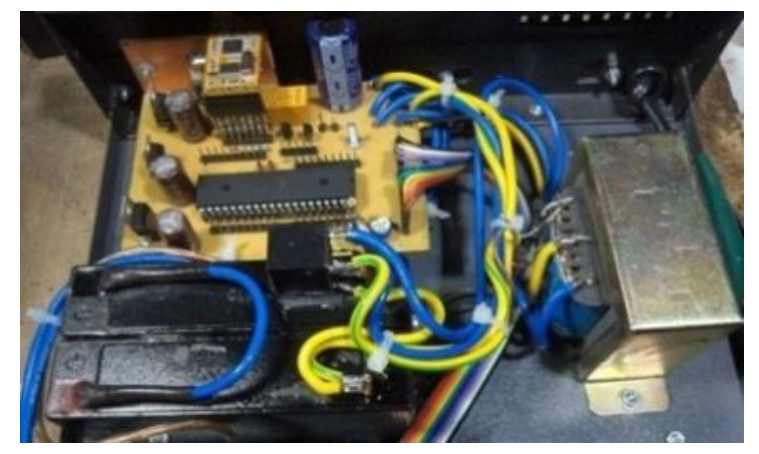

Gambar 10. Realisasi perangkat keras (hardware) Remote Controller

\subsubsection{Perancangan dan Realisasi Perangkat Keras Master Controller}

Blok diagram sistem untuk perangkat Remote Controller ditunjukkan pada Gambar 11.

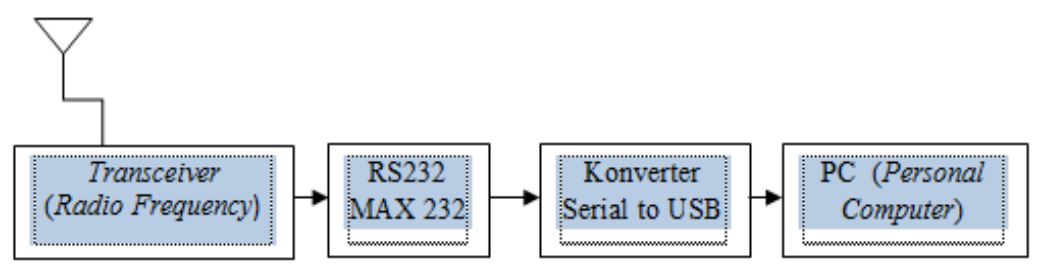

Gambar 11. Blok diagram perangkat Master Controller 
Berdasarkan blok diagram gambar 4 perangkat Master Controller terdiri dari subsistem :

1. Subsistem Pemantauan (Monitoring)

$$
\text { PC (Personal Computer) }
$$

2. Subsistem Komunikasi Serial

Transceiver RF (Radio Frequency) APC220 dan memanfaatkan IC MAX232 pada RS232 sebagai interface komunikasi data serial

\section{Subsistem Pemantauan (Monitoring)}

Pada subsistem pemantauan (monitoring) digunakan sebuah PC (Personal Computer) sebagai piranti yang akan menampilan informasi dan perintah pada Master Controller dengan menggunakan software Visual Basic 6.0.

\section{Subsistem Komunikasi Serial}

Subsistem komunikasi serial yang digunakan yaitu berupa transceiver RF (Radio Frequency) APC220 yang dapat menerima informasi pada perangkat Master Controller serta dapat mengirimkan perintah pada mikrokontroller yang berada pada perangkat Remote Controller. Dalam subsistem ini terdapat IC MAX232 sebagai konverter yang mengubah sinyal level RS232 dari komputer menjadi sinyal level TTL pada modul RF APC220. Gambar 12 menunjukkan skematik dari komunikasi serial untuk modul RF APC220 terhadap PC (Personal Computer).

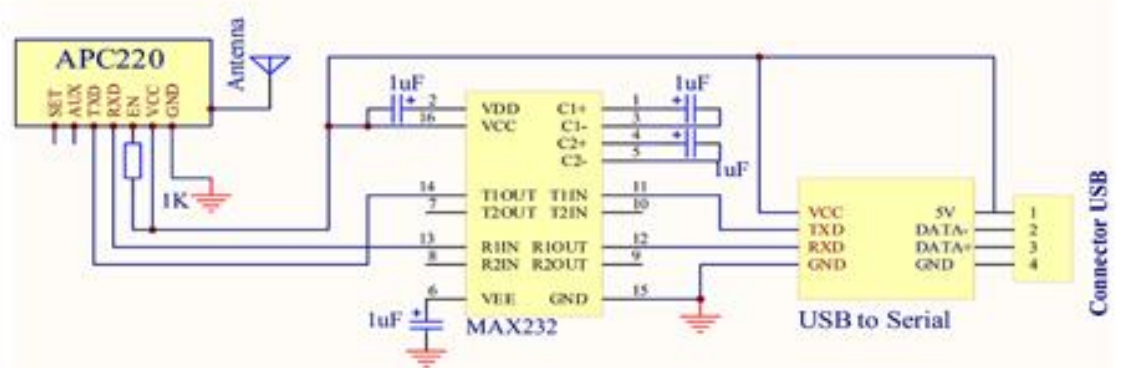

Gambar 12. Skematik komunikasi serial modul RF APC220 terhadap PC (Personal Computer)

Realisasi perangkat komunikasi serial pada modul RF (Radio Frequency) APC220 yang akan dihubungkan pada PC, ditunjukkan oleh Gambar 13.

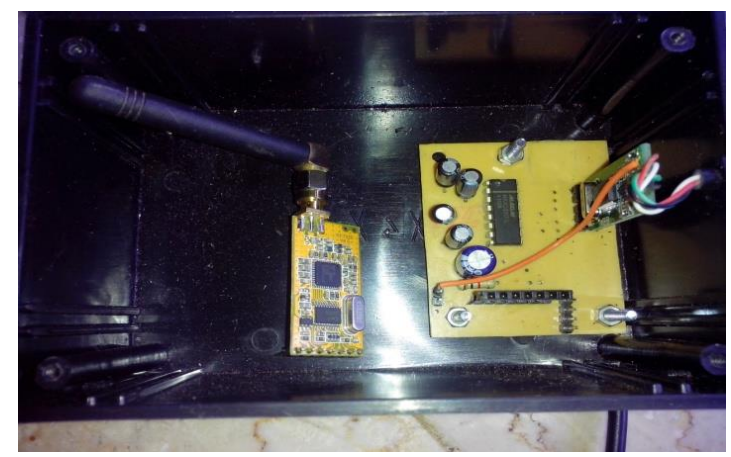

Gambar 13. Realisasi komunikasi serial modul RF APC220 terhadap PC (Personal Computer) 


\subsection{Perancangan dan Realisasi Perangkat Lunak (Software) \\ 2.3.1 Perancangan dan Realisasi Perangkat Lunak Remote Controller}

Diagram alir (flowchart) pada perangkat Remote Controller ditunjukkan pada Gambar 14.

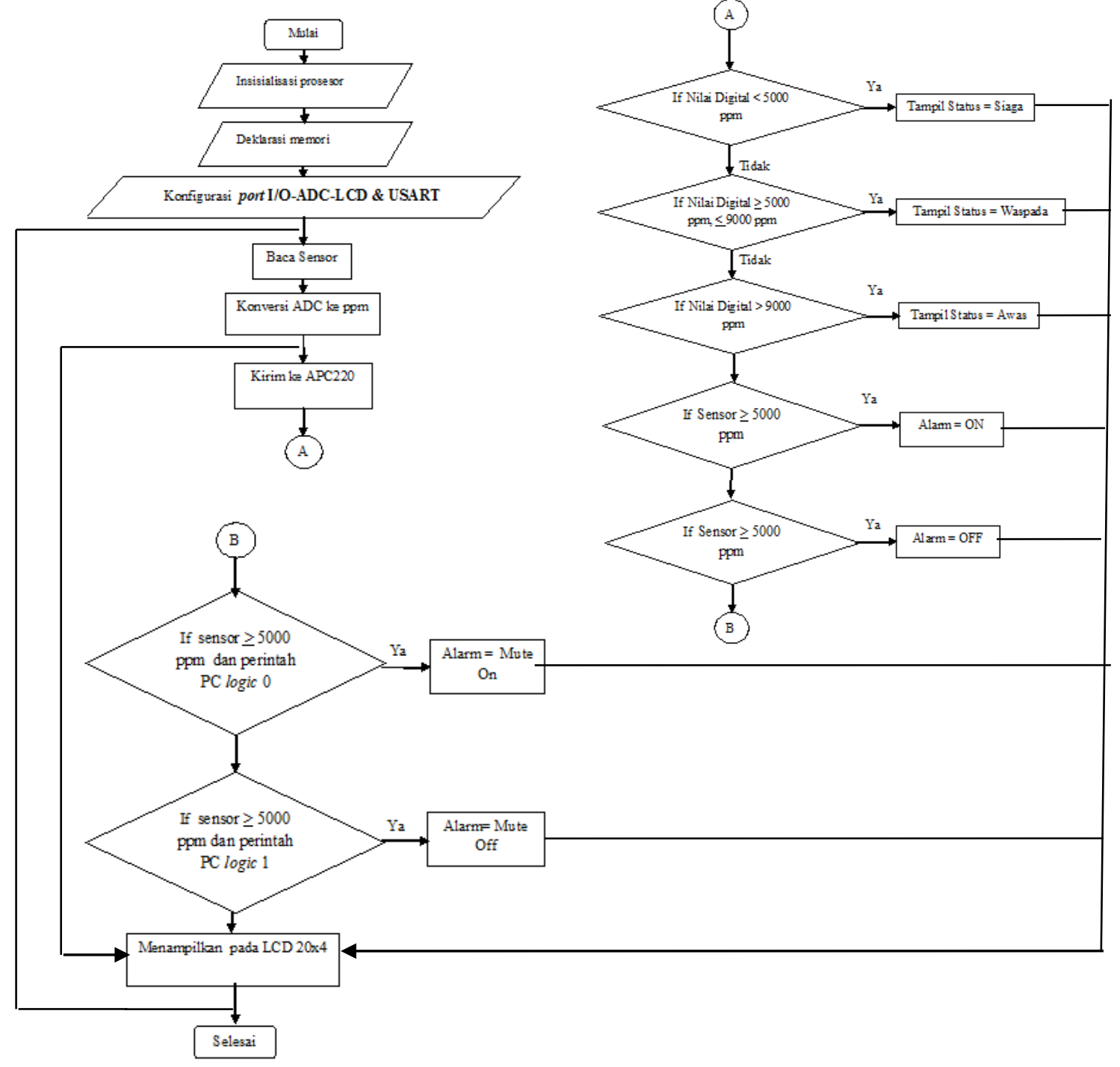

Gambar 14. Diagram alir (flowchart) pada Remote Controller

Untuk algoritma dari diagram alir (flowchart) Remote Controller dari Gambar 14 yaitu sebagai berikut:

1. Menginisialisasi prosesor yaitu seperti kristal dan baudrate yang yang akan dipakai

2. Mendeklarasikan memori yang akan dipakai pada mikrokontroller

3. Mengkonfigurasi port-port pada mikrokontroller yang difungsikan sebagai input dan output serta mengkonfigurasi tipe LCD yang dipakai yaitu 20x4

4. Membaca sensor sebagai inputan pada ADC mikrokontroller

5. Mengkonversikan ADC menjadi satuan ppm pada mikrokontroller

6. Data berupa besarnya tegangan input pada ADC dan nilai hasil konversi $A D C$ mikrokontroller akan dikirimkan melalui RF APC220

7. Membuat tampilan pada LCD

8. Menampilkan kadar konsentrasi gas terbaca dalam satuan ppm

9. Mengatur status keadaan berdasarkan kadar konsentrasi yang terbaca 
a. Jika konsentrasi terbaca < 5000 ppm, maka status dinyatakan "SIAGA"

b. Jika konsentrasi terbaca $>5000 \mathrm{ppm}$ dan $\leq 9000 \mathrm{ppm}$, maka status dinyatakan "WASPADA"

c. Jika konsentrasi terbaca > 9000 ppm, maka status dinyatakan "AWAS"

10. Pengaktifan alarm berdasarkan kadar konsentrasi gas yang terbaca

a. Jika konsentrasi gas $\geq 5000$ ppm, maka alarm akan aktif

b. Jika konsentrasi gas < 5000 ppm, maka alarm tidak aktif

11. Mengatur status alarm berdasarkan perintah PC

a. Jika alarm aktif dan PC diberi logika 1 (high), maka kondisi mute on aktif

b. Jika alarm aktif dan PC diberi logika 0 (low), maka mute off aktif

12. Keseluruhan data yang telah diolah akan ditampilkan pada LCD

Berdasarkan diagram alir pada perangkat Remote Controller, Realisasi dari perangkat lunak (software) untuk tampilan pada LCD ditunjukkan pada Gambar 15.

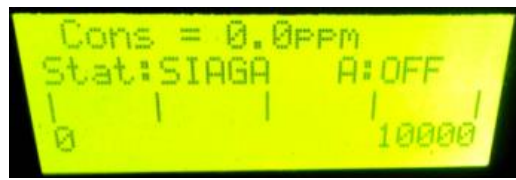

Gambar 15. Realisasi perangkat lunak (software) untuk tampilan pada LCD

\subsubsection{Perancangan dan Realisasi Perangkat Lunak Master Controller}

Diagram alir (flowchart) pada perangkat Master Controller ditunjukkan pada Gambar 16.

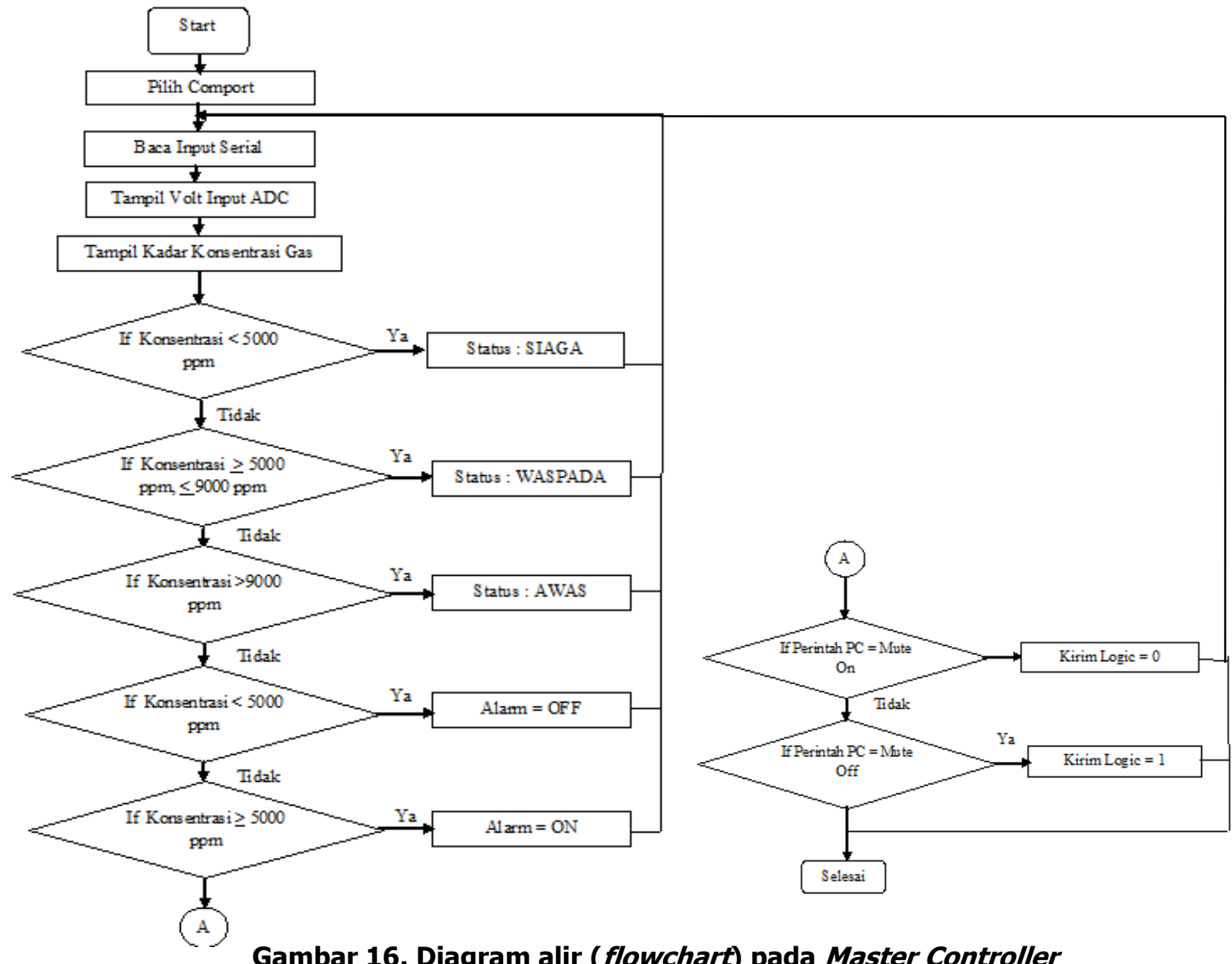


Untuk algoritma dari diagram alir (flowchart) Remote Controller dari Gambar 14 yaitu sebagai berikut:

1. Memilih Comport (Command port) yang akan digunakan

2. Membaca informasi atau data yang telah diterima oleh modul RF APC220 yang berada pada Master Controller

3. PC akan menampilkan besarnya nilai tegangan (voltage) yang merupakan tegangan output yang dihasilkan pada sensor MQ5 yang akan masuk pada ADC mikrokontroller

4. PC akan menampilkan kadar konsentrasi gas dalam satuan ppm

5. Mengatur status keadaan gas yang akan tertampil berdasarkan kadar konsentrasi yang terbaca

a. Jika konsentrasi terbaca $<5000$ ppm, maka status dinyatakan "SIAGA"

b. Jika konsentrasi terbaca $\geq 5000 \mathrm{ppm}$ dan $\leq 9000 \mathrm{ppm}$, maka status dinyatakan "WASPADA"

c. Jika konsentrasi terbaca > 9000 ppm, maka status dinyatakan "AWAS"

6. Mengirimkan perintah pada mikrokontroller berdasarkan logika yang diberikan pada PC

a. Jika alarm aktif dan PC diberi logika 1 (high), maka kondisi mute on aktif

b. Jika alarm aktif dan PC diberi logika 0 (low), maka kondisi mute off aktif

Realisasi dari perancangan perangkat lunak (software) pada Master Controller terlihat pada tampilan PC (Personal Computer) berupa monitor kualitas udara yang didesain dari pemograman Visual Basic 6.0 dan ditunjukkan pada Gambar 17.

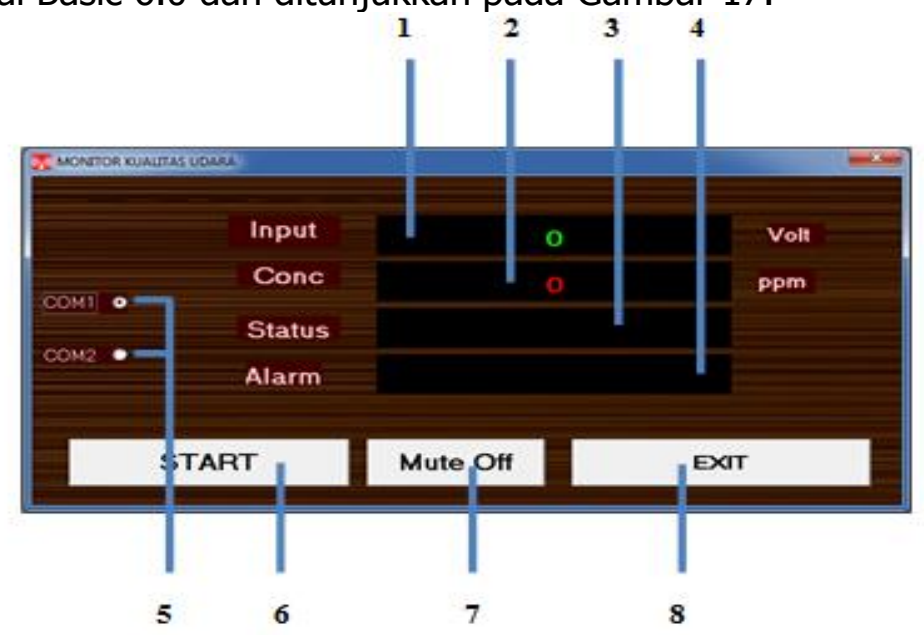

Gambar 17. Tampilan visual monitor kualitas udara pada PC

Keterangan:

(1) Sebagai tampilan nilai tegangan input pada ADC mikrokontroller dalam satuan volt.

(2) Sebagai tampilan kadar konsentrasi gas digital dalam satuan ppm.

(3) Menampilkan status kondisi berdasarkan kadar konsentrasi yang terbaca oleh sistem.

(4) Menunjukkan kondisi alarm (ON/OFF)

(5) Menunjukkan series COM yang digunakan pada PC.

(6) Tombol START untuk memulai kerja tampilan pada PC.

(7) Tombol (Mute On/Mute Off) untuk mengaktifkan perintah mute terhadap sistem alarm.

(8) Tombol EXIT untuk mengakhiri kerja tampilan pada PC. 


\subsection{Konversi Tegangan Menjadi part per million (ppm)}

Konversi tegangan dari satuan volt menjadi part per million ( $\mathrm{ppm}$ ) berada pada Analog to Digital Converter (ADC) pada mikrokontroller ATmega16. ADC (Analog to Digital Converter) merupakan interface yang dapat mengubah tegangan analog menjadi pulsa digital. Pada ADC 8 bit, rentang output yang dihasilkan adalah $2^{8}=256$. Sedangkan $A D C 10$ bit yang berada pada mikrokontroller AVR ATmega16 ini lebih besar yaitu $2^{10}=1024$. Persamaan 1 berikut ini merupakan perumusan untuk menentukan hasil konversi ADC (Analog to Digital Converter).

$$
\text { Konversi ADC }=\frac{\text { Vin }}{\text { Vref }} \times 1024
$$

Pada sistem monitoring pendeteksi kebocoran gas LPG ini, range pengukuran ppm yang akan dipakai yaitu dari 200 ppm sampai dengan 10000 ppm. Tegangan referensi yang digunakan yaitu sebesar $5 \mathrm{~V}$. Jadi apabila input ADC bernilai $5 \mathrm{~V}$ maka akan setara dengan nilai 9800 ppm. Sehingga kenaikan X/ppm per 1 bitnya yang ditunjukkan pada persamaan 2 berikut:

$$
X=\frac{\text { Range }}{\text { Total bit }}=\frac{10000-200}{1024}=\frac{9800}{1024}=9.5703125
$$

Sehingga untuk mendapatkan konversi ke satuan ppmnya menjadi:

$$
\text { ppm }=\mathrm{X} * \text { Konversi_ADC }
$$

Walaupun pada mikrokontroller ATmega16 ini terdapat 8 port ADC, namun pada rangkaian sistem ini hanya akan digunakan 1 port ADC saja, yaitu pada PAO (pin 40) Mikrokontroller ATmega16.

\subsection{Sistem Koneksi Pada RF APC220}

Dalam komunikasi data serial pda RF APC220 terdapat 2 (dua) buah modul yaitu modul RF yang dihubungkan pada perangkat Remote Controller dan modul yang terhubung pada perangkat Master Controller.

Dalam (datasheet APC220) untuk koneksi antar modul, dapat diatur dengan pengaturan frekuensi yang sama. Untuk mengatur parameter pada masing-masing modul dapat menggunakan perangkat lunak (software) ( $R F-A N E T$ ) melalui PC (Personal Computer). Pengaturan terhadap parameter tersebut dapat terlihat pada Gambar 18.

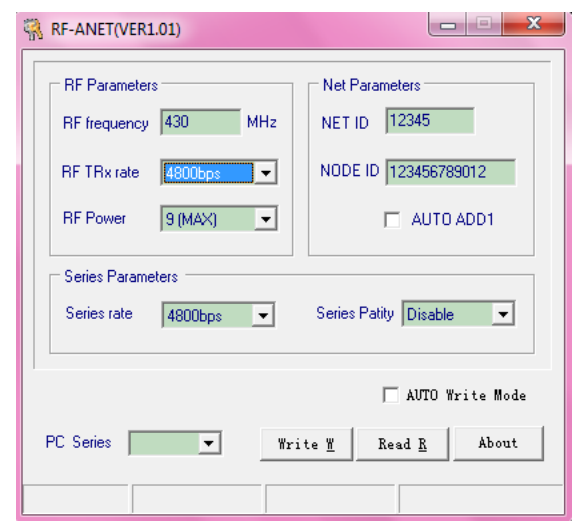

Gambar 18. Perangkat lunak (software) RF-ANET pada APC220 


\section{PENGUJIAN DAN ANALISIS}

\subsection{Pengujian dan Analisis Perangkat Remote Controller}

\subsubsection{Pengujian Sensor}

Dalam pengaplikasiannya, sensor MQ5 dihubungkan pada konektor yang dapat dihubungkan pada modul yang berada pada Remote Controller, seperti terlihat pada Gambar 19.

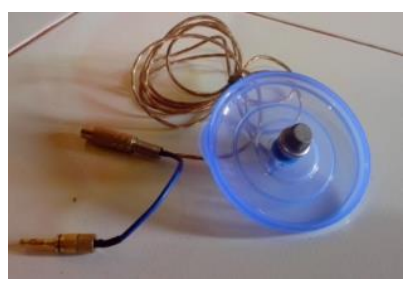

\section{Gambar 19. Sensor MQ5 yang terhubung kabel konektor}

Pengujian terhadap sensor gas MQ5 dilakukan, untuk melihat apakah sensor gas ini, telah atau dapat bekerja sesuai dengan yang diharapkan, dengan menguji tegangan output dari sensor, dan mencari konsentrasinya melalui perumusan konversi, lalu membandingkan konsentrasi perhitungan tersebut dengan konsentrasi yang ditampilkan pada LCD. Hasil pengujian terhadap sensor gas MQ5 dapat dilihat pada Tabel 1.

Tabel 1. Pengujian Sensor

\begin{tabular}{|c|c|c|c|}
\hline $\begin{array}{c}\text { Tegangan } \\
\text { Output Sensor } \\
\text { Terukur (Volt) }\end{array}$ & $\begin{array}{c}\text { Konsentrasi } \\
\text { Hasil } \\
\text { Perumusan } \\
(\mathbf{p p m})\end{array}$ & $\begin{array}{c}\text { Konsentrasi } \\
\text { Tertampil Pada } \\
\text { LCD (ppm) }\end{array}$ & $\begin{array}{c}\text { Selisih } \\
(\mathbf{p p m})\end{array}$ \\
\hline 2,15 & 4214 & 4180 & 34 \\
\hline 2,38 & 4664,8 & 4636 & 28.8 \\
\hline 2,84 & 5566,4 & 5548 & 18,4 \\
\hline 2,87 & 5625,2 & 5605 & 20,2 \\
\hline 3,17 & 6213,2 & 6175 & 38,2 \\
\hline
\end{tabular}

\subsubsection{Pengujian Mikrokontroller}

Pengujian pada mikrokontroller dilakukan dengan mengujikan program yang telah dibuat dalam bentuk simulasi menggunakan program Proteus 8 Profesional. Langkah pertama dengan membuat skematik rangkaian mikrokontroller sederhana, seperti Gambar 20. 


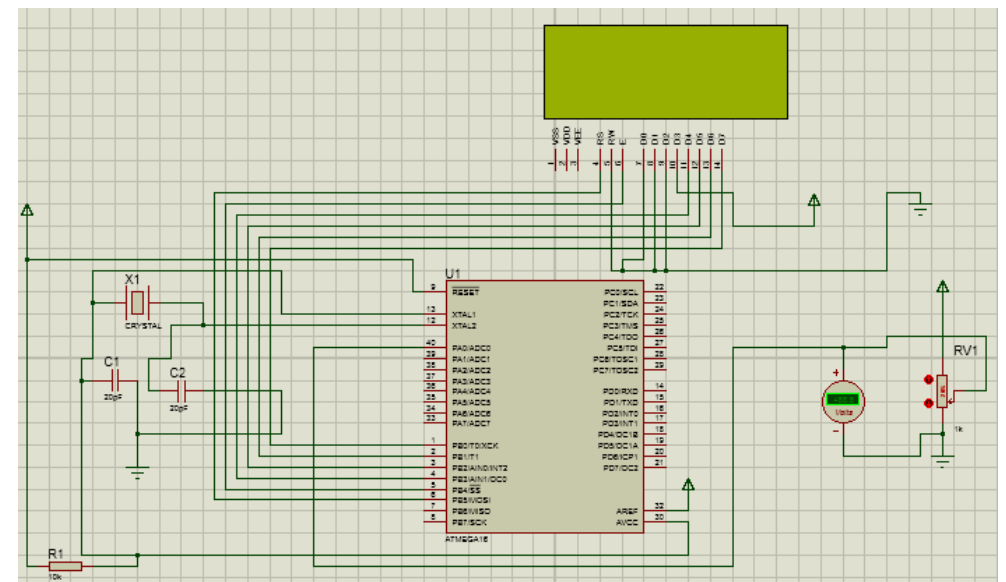

Gambar 20. Skematik rangkaian mikrokontroller sederhana

Pengujian ini dilakukan dengan mengkompilasi program yang telah dibuat, sehingga akan terlihat program akan berjalan sesuai dengan yang diharapkan atau tidak. Hasil pengujian terhadap tampilan simulasi untuk mikrokontroller terlihat pada Gambar 21.

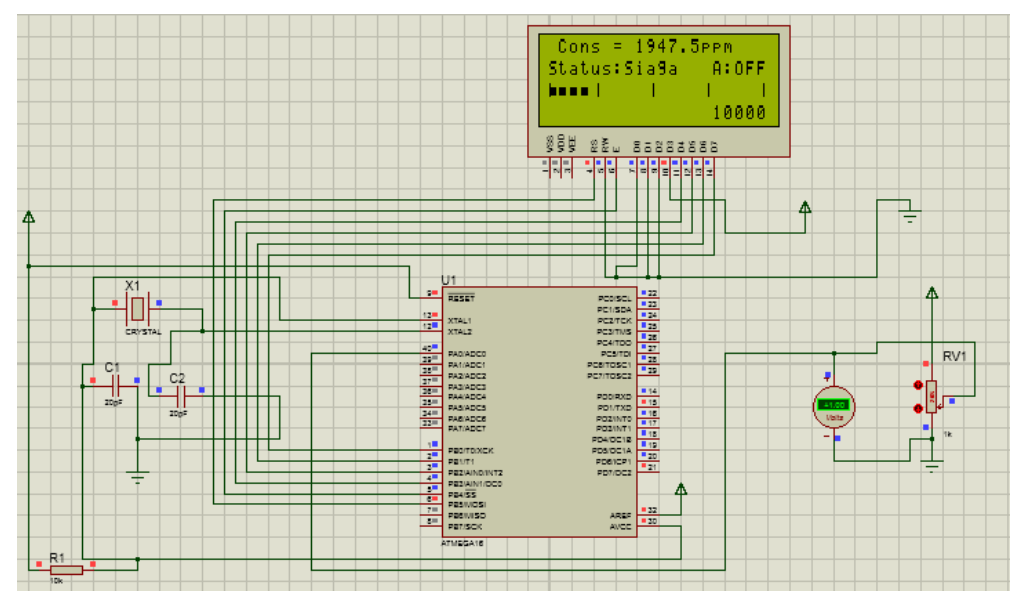

Gambar 21. Tampilan simulasi setelah program dijalankan

\subsubsection{Pengujian Display (Tampilan) LCD}

Pengujian dilakukan pada perangkat yang berada pada Remote Controller dengan membandingkan tampilan LCD sebelum dan setelah modul perangkat elektronik terkoneksi pada kabel konektor yang terhubung pada sensor MQ5 yang terlihat pada Gambar 22 dan 23.

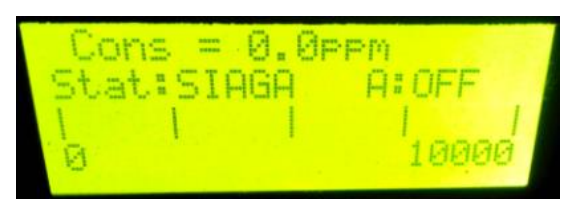

Gambar 22. Tampilan LCD sebelum terkoneksi sensor gas MQ5

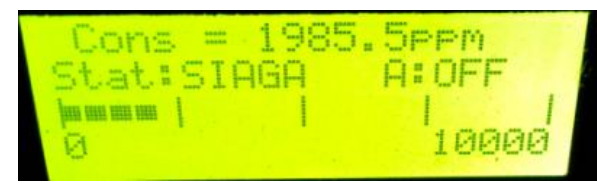

Gambar 23. Tampilan LCD setelah terkoneksi gas MQ5 


\subsubsection{Pengujian Alarm}

Untuk pengujian terhadap alarm ini dilakukan dengan melihat kerja sistem, yaitu apabila sensor mendeteksi kebocoran gas LPG dengan konsentrasi yang melebihi 5000 ppm, maka mikrokontroller ATmega16 akan mengirimkan logika 1 melalui port PD2 pada sistem alarm yang menyebabkan buzzer dan lampu indikator aktif, Dan apabila konsentrasi kurang dari 5000 ppm, maka port PD2 akan mengirimkan logika 0 sehingga sistem alarm tidak aktif. Hasil pengujian terhadap alarm ini ditunjukkan pada Tabel 2.

Tabel 2. Hasil Pengujian Alarm Pada Sistem

\begin{tabular}{|l|c|c|c|c|c|}
\hline \multirow{2}{*}{$\begin{array}{c}\text { Kadar } \\
\text { Konsentrasi } \\
\text { Gas }\end{array}$} & $\begin{array}{l}\text { Perintah } \\
\text { Logika }\end{array}$ & \multicolumn{2}{|c|}{ Buzzer } & \multicolumn{2}{c|}{ Lampu Indikator } \\
\cline { 3 - 6 } & & Tegangan & Ket. & Tegangan & Ket. \\
\hline ppm $<5000$ & 0 & $0 \mathrm{~V}$ & Tdk Aktif & $0 \mathrm{~V}$ & Tdk Aktif \\
\hline $\mathrm{ppm} \geq 5000$ & 1 & $11,21 \mathrm{~V}$ & Aktif & $2,97 \mathrm{~V}$ & Aktif \\
\hline
\end{tabular}

\subsection{Pengujian dan Analisis Perangkat Master Controller}

Pengujian pada perangkat Master Controller dilakukan dengan melihat tampilan pada PC yaitu tampilan pada form monitor kualitas udara yang telah dibuat melalui pemograman VB 6.0.Setelah program pada VB 6.0 dijalankan, form monitor kualitas udara akan muncul seperti yang terlihat pada Gambar 24.

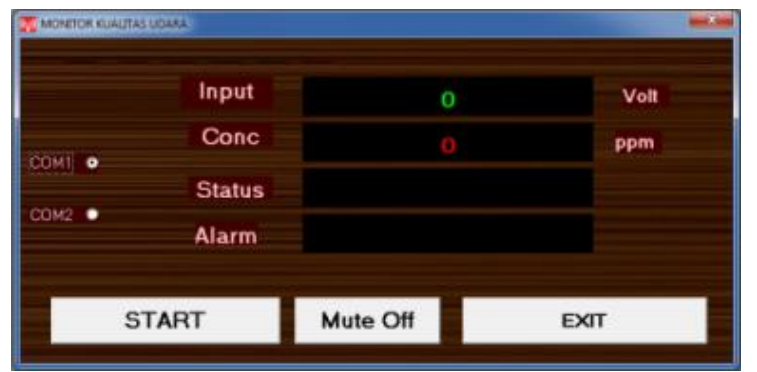

\section{Gambar 24. Tampilan monitor kualitas udara sebelum dimulai}

Sistem monitoring ini dapat dimulai setelah tombol "START" diaktifkan. Informasi berupa data-data yang telah dikirimkan sebelumnya dari perangkat Remote Controller akan ditampilkan pada form monitor kualitas udara, seperti yang terlihat pada Gambar 25.

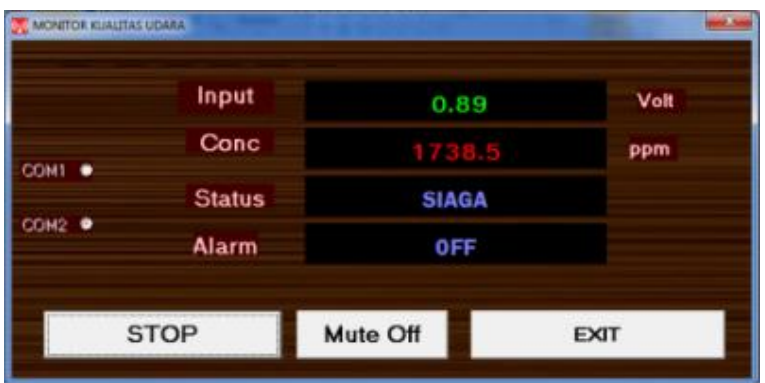

Gambar 25. Tampilan monitor kualitas udara setelah dimulai 


\subsection{Pengujian dan Analisis Pengiriman Data Serial}

Pengujian ini bertujuan untuk mengetahui kemampuan RF APC220. Kemampuan tersebut dapat diujikan dengan melihat keberhasilan RF APC220 dalam mengirimkan informasi atau data dari Remote Controller ke Master Controller pada jarak-jarak tertentu. Pengujian terhadap keberhasilan pengiriman data dilakukan dengan menggunakan software kylcom demo transceiver yanng terdapat pada PC. Terlihat pada tabel 3. Sedangkan untuk pengujian jarak antara perangkat Remote Controller dan Master Controller ditunjukkan pada Gambar 26.

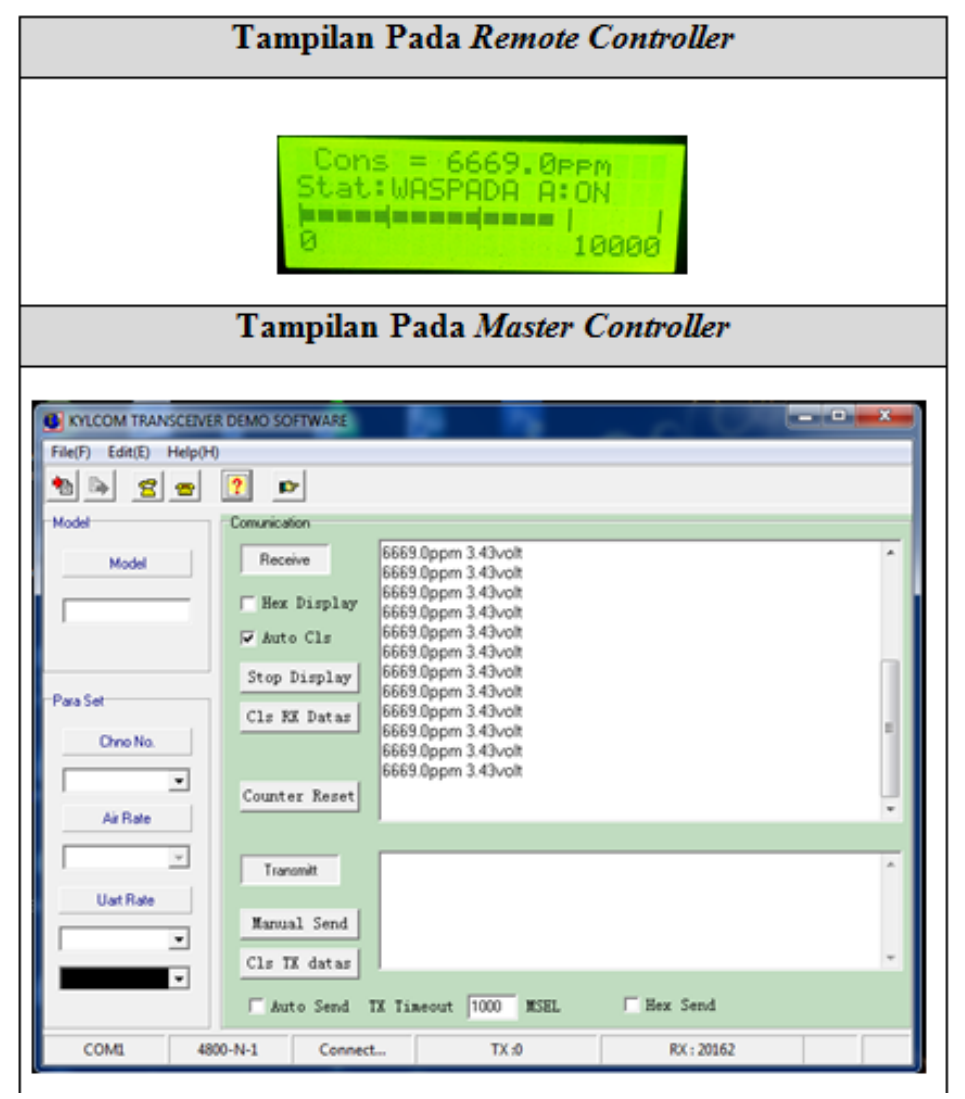

Gambar 26. Hasil pengujian keberhasilan pengiriman data

Untuk pengujian terhadap jarak antara Remote Controller dan Master Controller terlihat pada Tabel 3.

Tabel 3. Hasil Pengujian Jarak RF APC220

\begin{tabular}{|c|c|}
\hline Jarak & Status Pengiriman Data \\
\hline 5 meter & Berhasil \\
\hline 10 meter & Berhasil \\
\hline 50 meter & Berhasil \\
\hline 100 meter & Berhasil \\
\hline 200 meter & Berhasil \\
\hline 250 meter & Tidak Berhasil \\
\hline 275 meter & Tidak Berhasil \\
\hline 300 meter & Tidak Berhasil \\
\hline
\end{tabular}


Berdasarkan hasil dari pengujian terhadap jarak, sistem ini dapat berjalan dengan baik jika jarak antara Remote Controller dan Master Controller tidak lebih dari 200 meter. Hal ini jika dilihat dari spesifikasi APC220 dapat dikatakan kurang maksimal, karena jarak optimal sistem hanya sebesar $20 \%$ dari jarak maksimal pada spesifikasi modul.

\subsection{Pengujian Sistem Keseluruhan}

Pengujian sistem keseluruhan merupakan gabungan dari pengujian pada perangkat Remote Controller dan perangkat Master Contoller baik pengujian terhadap (hardware) maupun (software).

\subsubsection{Pengujian Display (Tampilan) LCD dan PC}

Pengujian dilakukan dengan membagi atas 2 (dua) kategori pengujian, yaitu berdasarkan pada kondisi alarm dan berdasarkan pada status keadaan

\section{a. Pengujian dengan Tampilan Berdasarkan Kondisi Alarm}

Tabel 4. Pengujian Tampilan LCD dan PC Berdasarkan Kondisi Alarm

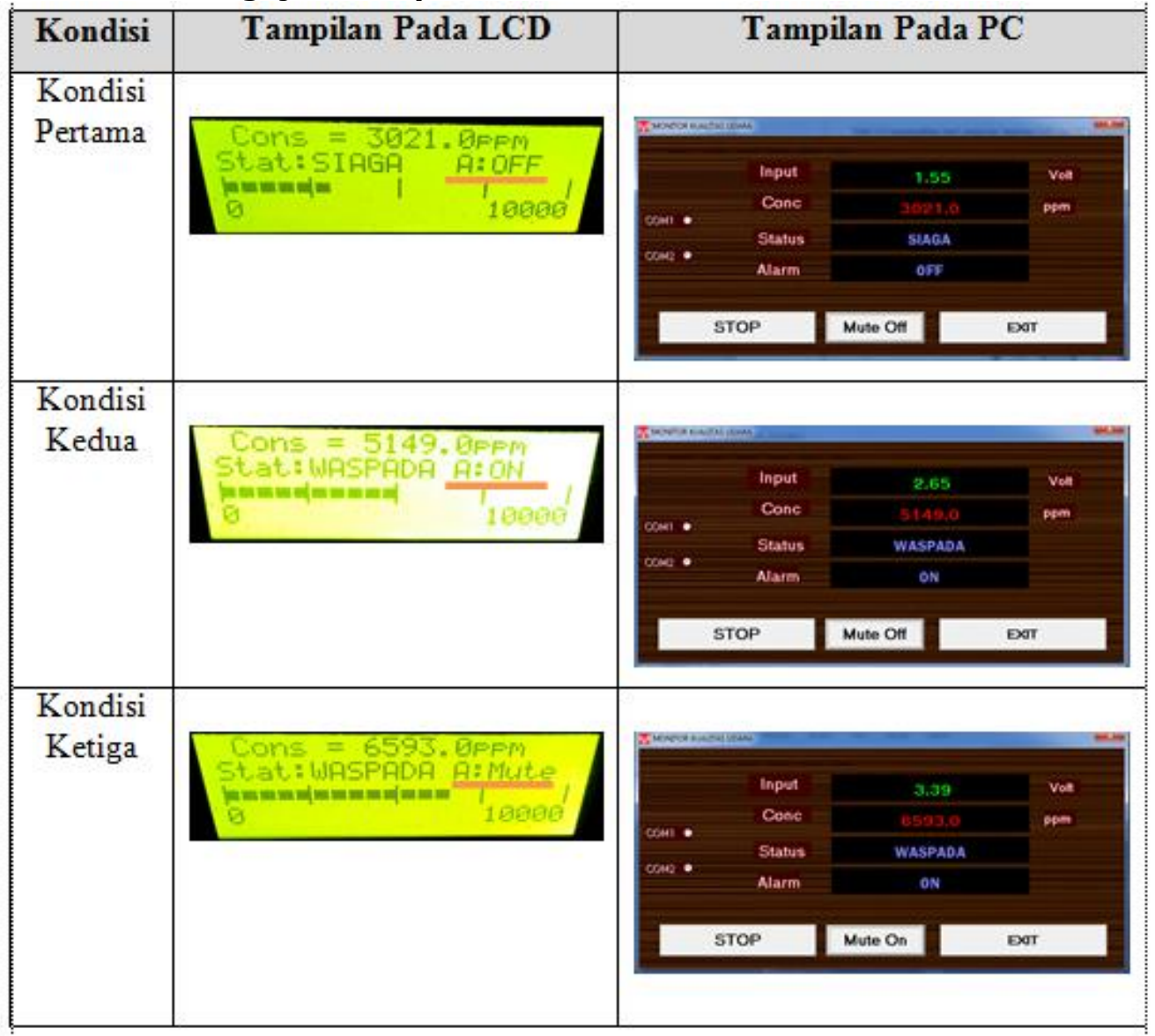

Dari hasil pengujian terhadap tampilan LCD dan PC, berdasarkan kondisi alarm ini sistem monitoring pendeteksi gas LPG ini terbagi menjadi 3 (tiga) kondisi yaitu: OFF, ON, Mute. 
b. Pengujian dengan Tampilan Berdasarkan Status Keadaan

Tabel 5. Pengujian Tampilan LCD dan PC Berdasarkan Status Keadaan

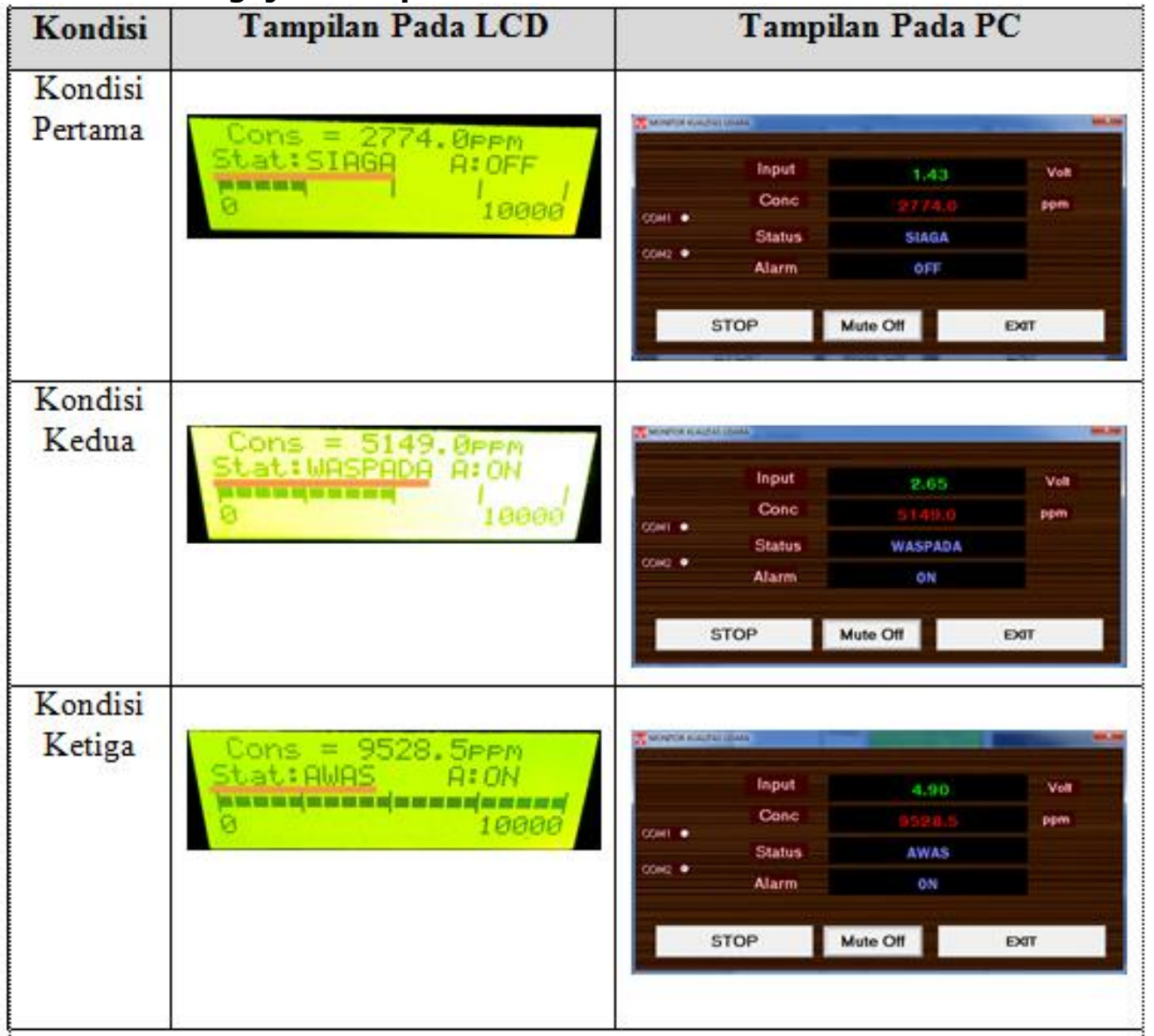

Dari hasil pengujian terhadap tampilan LCD dan PC, berdasarkan status keadaan ini, sistem monitoring pendeteksi gas LPG ini terbagi menjadi 3 (tiga) kondisi yaitu: SIAGA, WASPADA, AWAS.

\subsubsection{Pengujian dan Analisis Sensor MQ5}

Pengujian terhadap sensor MQ5 ini, dilakukan untuk membandingkan kadar konsentrasi MQ5 yang didapatkan dari perhitungan ADC Mikrokontroller ATmega16 dengan kadar konsentrasi yang telah ditampilkan pada tampilan (display) LCD maupun pada PC. Data hasil pengujian terhadap Sensor MQ5 ditunjukkan pada Tabel 6. 
Tabel 6. Data Hasil Pengujian Sensor MQ5

\begin{tabular}{|c|c|c|c|c|}
\hline No. & $\begin{array}{c}\text { Vout Sensor } \\
(\mathbf{v o l t})\end{array}$ & $\begin{array}{c}\text { Konsentrasi } \\
\text { hitung (ppm) }\end{array}$ & $\begin{array}{c}\text { Konsentrasi Tertampil } \\
\text { pada LCD dan PC (ppm) }\end{array}$ & $\begin{array}{c}\text { Selisih } \\
(\mathbf{p p m})\end{array}$ \\
\hline 1. & 0,95 & 1862 & 1852,5 & 9,5 \\
\hline 2. & 1,05 & 2058 & 2042,5 & 15,5 \\
\hline 3. & 1,55 & 3038 & 3011,5 & 26,5 \\
\hline 4. & 2,65 & 5194 & 5158,5 & 35,5 \\
\hline 5. & 3,10 & 6076 & 6032,5 & 43,5 \\
\hline 6. & 3,75 & 7350 & 7296,0 & 54 \\
\hline 7. & 4,25 & 8330 & 8265,0 & 65 \\
\hline 8. & 4,45 & 8722 & 8654,5 & 67,5 \\
\hline 9. & 4,65 & 9114 & 9044,0 & 70 \\
\hline 10. & 5,00 & 9800 & 9718,5 & 81,5 \\
\hline
\end{tabular}

\section{KESIMPULAN}

Berdasarkan hasil perancangan, realisasi dan pengujian terhadap sistem monitoring pendeteksi kebocoran gas LPG dapat disimpulkan bahwa :

1. Berdasarkan pengujian terhadap perangkat Remote Controller, dapat dikatakan bahwa komponen-komponen di dalamnya telah berfungsi sesuai dengan yang diharapkan.

2. Tampilan terhadap sistem monitoring yang berada pada perangkat Master Controller dapat divisualisasikan dengan baik berdasarkan pengujian yang dilakukan sebelumnya.

3. Pengujian yang dilakukan terhadap komunikasi serial menunjukkan bahwa data yang yang diinformasikan dapat ditransmisikan dengan baik, dengan jarak pengujian mencapai \pm 200 meter, kondisi berpenghalang.

4. Secara keseluruhan, sistem telah berhasil direalisasikan, dimana pada bagian perangkat Remote Controller yang mampu mendeteksi apabila terjadi kebocoran gas LPG serta dapat melakukan pemantauan dari jarak jauh melalui visualisasi dari perangkat Master Controller.

\section{DAFTAR RUJUKAN}

BPKN. (2010). Data Kasus Ledakan Tabung Gas LPG.- Dipetik pada tanggal 23 Juni 2014 jam 1:46 dari http://www.infosketsa.com/

Kirom, Hudal Ilal. dkk. (2013). Sistem Monitoring Kebocoran Gas LPG (Liquefied Petroleum Gas) Pada Smart Building Berbasis TCP/IP. Jurnal Teknik Kontrol Otomatik Jurusan Teknik Elektro Universitas Diponegoro Semarang, vol 3, no.2.

Nurhidayat, Arif. (2010). Pengembangan dan Evaluasi Sistem Peringatan Dini Kebocoran LPG Rumah Tangga. Depok: Universitas Indonesia.

Tim Parallax. (2012). Datasheet MQ 5. Diakses tanggal 24 September 2012 jam 14:45 WIB dari http://parallax.com/sites/default/files/downloads/605-00009-MQ-5-Datasheet.pdf 
Tim Parallax. (2012). Datasheet APC220. Diakses pada tanggal 15 Agustus 2013 jam 10:38 WIB dari http://www.dfrobot.com/image/data/TEL0005/APC220_Datasheet.pdf

Wibowo, Pusdriyanto. (2012). Kelebihan dan Kekurangan Wireless. Dipetik pada tanggal 2 Januari 2015 jam 17:41 dari http://pusdrianto.blogspot.com/ 